\title{
Highway urbanization and Land conflicts: the challenges to decentralization in India
}

\section{Citation}

Balakrishnan, Sai. 2013. “Highway Urbanization and Land Conflicts: The Challenges to Decentralization in India." Pacific Affairs 86 (4) (December 1): 785-811. doi:10.5509/2013864785. http://dx.doi.org/10.5509/2013864785.

\section{Published Version}

10.5509/2013864785

\section{Permanent link}

http://nrs.harvard.edu/urn-3:HUL.InstRepos:27731428

\section{Terms of Use}

This article was downloaded from Harvard University's DASH repository, and is made available under the terms and conditions applicable to Other Posted Material, as set forth at http:// nrs.harvard.edu/urn-3:HUL.InstRepos:dash.current.terms-of-use\#LAA

\section{Share Your Story}

The Harvard community has made this article openly available.

Please share how this access benefits you. Submit a story.

Accessibility 


\title{
Highway Urbanization and Land Conflicts: The Challenges to Decentralization in India
}

\author{
Sai Balakrishnan
}

\begin{abstract}
Much of the urban growth in developing countries is taking place along infrastructure corridors that connect cities. The villages along these corridors are frenzied and contested sites for the consolidation and conversion of agricultural lands for urban uses. The scale of changes along these corridors is larger than the political jurisdiction of local governments, and new regional institutions are emerging to manage land consolidations at this corridor scale. This article compares two inter-urban highways in India and the hybrid regional institutions that manage them: the BangaloreMysore corridor, regulated by parastatals, and the Pune-Nashik corridor, by cooperatives. It traces the emergence of parastatals and cooperatives to the turn of the twentieth century, the ways in which these old institutions are being reworked to respond to the contemporary challenges of highway urbanization, and the winners and losers under these new institutional arrangements. I use the term "negotiated decentralization" to more accurately capture the back-and-forth negotiations between local, regional and state-level actors that leads to context-specific regional institutions like the parastatals and cooperatives.
\end{abstract}

KEYWORDS: highway urbanization, land conversion, land conflicts, cooperatives, parastatals, regional institutions

DOI: http:/ /dx.doi.org/10.5509/2013864785

\section{Introduction}

7 he 160 villages along the Bangalore-Mysore highway in India, connecting the cities of Bangalore and Mysore, are schizophrenic

( patchworks of agricultural fields, industrial parks, gated communities and informal settlements. Property developers and industrialists are attracted to these highway villages with their cheaper lands and adjacencies to the well-connected highway. Agrarian landowners in these villages are threatened that these new developments will deprive them of their lands and livelihoods. These villages are fraught with contestations between real estate developers, industrialists and agrarian landowners over land acquisitions and, more broadly, the distribution of costs and benefits of the new highway 
developments. The Bangalore-Mysore highway represents an emerging pattern of urbanization in developing countries: the urbanization along inter-urban highways. Since traditional institutions, like village governments for villages and municipalities for cities, collapse in these contested territories of overlapping cities and villages, what are the new regional institutions that can efficiently and equitably allocate land amongst competing interests and uses at a regional, i.e., highway, scale? To answer this question, I use a comparative case study method of two highways in India: the BangaloreMysore highway in South India, regulated by parastatals, and the Pune-Nashik highway in West India, regulated by farmer-owned land cooperatives. Both parastatals and cooperatives are regional institutions so their jurisdiction is translocal. Both of them are hybrid institutions, i.e., parastatals are public institutions that incorporate market values, and cooperatives are market institutions that incorporate social values. Parastatals, unlike "generalpurpose governments" like municipalities, have more of a market orientation in their financial discretion, internal organizational flexibility, and lower levels of citizen participation and accountability. ${ }^{1}$ The cooperatives are institutions that have emerged to remedy the institutional flaws of the pure market, and have more of a social orientation through democratic worker control of the production process and profit making under non-exploitative, more humane conditions. ${ }^{2}$

This article highlights the challenges of democratic decentralization, i.e., devolving decision-making authority to local village and city governments, in responding to the challenges of urbanization at a regional, highway scale. Using the models of parastatals and cooperatives, it takes a first step in articulating the major elements of the new hybrid regional institutions that are emerging as solutions to the new patterns of highway urbanization.

This article is based on nine months of fieldwork focusing on the large mega-projects that have been developed along the two case study corridors. For my qualitative research, I selected a cluster of 28 villages, located 30 kilometres from Bangalore city along the Bangalore-Mysore corridor, and 26 villages, located 42 kilometres from Pune city along the Pune-Nashik corridor. These sample villages are representative of the urbanization changes along the two case study highways. Through open-ended interviews with agrarian landowners who gave up their lands for the new highway developments, elected representatives of the villages, parastatal bureaucrats at the policy and implementation levels, and members of the land cooperatives, I mapped out the main institutional actors in the land consolidation process for these developments. Part 1 of this article sets the

\footnotetext{
1 Nancy Burns, The Formation of American Local Governments: Private Values in Public Institutions (New York: Oxford University Press, 1994); Kathryn A. Foster, The Political Economy of Special Purpose Government (Washington, DC: Georgetown University Press, 1997).

Willaim Foote Whyte and Kathleen King Whyte, Making Mondragon: The Growth and Dynamics of the Worker Cooperative Complex (Ithaca, New York: Cornell University, 1991).
} 
context with an introduction to the inter-urban corridors as an emergent pattern of urbanization, and the challenges it poses to decentralization. Part 2 is a narrative of the land consolidation processes surrounding the large mega-projects along the Bangalore-Mysore and Pune-Nashik highways. Part 3 highlights the main findings of this article. It points to the institutional history of parastatals and cooperatives in India, the reasons for their emergence at the turn of the twentieth century, the ways in which they are being reworked to cope with contemporary highway land conflicts and the performance of these regional institutions in allocating land equitably and democratically at the highway scale.

\section{Highway Urbanization and the Challenges to Decentralization}

The territorial transformations along Bangalore and Pune's highways are not an aberrant form of urbanization unique to these cities. They represent a new and developing pattern of urbanization in India: research forecasts that by 2021, 70 to 90 percent of India's urban population will live and work along highways, ${ }^{3}$ as well as in other developing countries. Recently the UNHABITAT has identified "urban corridors" as the "shape of things to come." In their 2008 report on the State of African Cities, HABITAT has focused on Africa's urban corridors, including the Cairo-Suez, Cairo-Alexandria and Cairo-Said highways in North Africa, the transnational Greater Ibadan-LagosAccra highway that cuts across Nigeria, Benin, Togo and Ghana in West Africa, the Nairobi-Mombasa and Kampala-Entebbe highways in East Africa, and the Johannesburg-Pretoria and Maputo-Johannesburg highways in South Africa. ${ }^{5}$ A central challenge to this type of highway urbanization is the absence of regional governance structures that can regulate their growth, leading to "institutional fragmentation," "continued spatial segregation of the urban poor," "private real estate interests shaping most new development" and "environmental challenges [due to urban sprawl]." ${ }^{6}$ The transnational highways like the 600-kilometre Greater Ibadan-Lagos-Accra one and the 1500-kilometre Beijing-Tokyo corridors complicate the institutional question as they cut across national boundaries, posing problems of fragmentation and poor coordination among sovereign states. ${ }^{7}$ Highway urbanization is emerging as a dominant narrative of urbanization not only in developing

\footnotetext{
K.C. Sivaramakrishnan and B.N. Singh, Paper on Urbanization (New Delhi: Government of India Planning Commission, 2001); K.C. Sivaramakrishnan, Growth in Urban India: Issues of Governance (New Delhi: Center for Policy Research, 2006).

4 UN-HABITAT, State of the World's Cities 2010-11: Bridging the Urban Divide (Nairobi: United Nations Human Settlements Program, 2010).

5 UN-HABITAT, The State of African Cities (Nairobi: United Nations Human Settlements Program, 2008).

UN-HABITAT, The State of A frican Cities, 69.

UN-HABITAT, The State of African Cities, 98-9.
} 
countries, but also in the "advanced industrial" ones. ${ }^{8}$ By 2050, the inter-state highways in the US are expected to accommodate 70 percent of the country's population growth and 80 percent of its employment growth. ${ }^{9}$

This research is set within the context of India's 1991 decentralization policies: the 73rd Constitutional Amendment Act for village governments and the 74th Constitutional Amendment for urban/city governments, aimed at the devolution of decision-making authority to urban and rural local governments. The evaluation of India's decentralization policies has attracted much scholarly and policy attention. ${ }^{10}$ These studies have focused almost exclusively on the allocation of public services, with little or no attention to the effects of decentralization on the allocation of land. The emerging trend of highway urbanization has major implications for decentralization theories and practices. First, as cities in developing countries expand into massive conurbations that have earned them the epithet of "endless cities," 11 there is a reverse trend in politics with the decentralization of decision making to city and village governments. Second, the urbanization along highways defies the binary classification of human settlements into urban and rural. Yet, decentralization reifies the urban-rural dichotomy through devolving decision making to urban and rural local governments. Third, as pointed out by regional planning scholars, "[t] oday, regional planning tends to refer almost entirely to metropolitan planning." ${ }^{12}$ But metropolitan institutions remain centred on the city as their unit of analysis and action and are unable to respond to political geographies like the inter-urban highways. In the few cases where the regional discourse expands to the scale of the highways, the analyses tend to be normative. For instance, the UN-HABITAT recommended establishing the Greater Ibadan-Lagos-Accra Authority as a "supra-national" institution to manage the Greater Ibadan-Lagos-Accra corridor in West Africa. ${ }^{13}$ But, these normative prescriptions remain pipe dreams, partly because there are other existing institutions that are already engaged in these planning tasks, and partly because there is no political incentive for

$8 \quad$ Robert E. Lang and Dawn Dhavale, “America's Megapolitan Areas," Land Lines 17, no. 3 (2005): 1-4; Margaret Dewar and David Epstein, "Planning for 'Megaregions' in the United States," Journal of Planning Literature 22, no. 2 (2007): 108-24.

9 Lang and Dhavale, "America's Megapolitan Areas"; Dewar and Epstein, "Planning for 'Megaregions."'

10 Raghabendra Chattopadhyay and Esther Duflo, "Women as Policy Makers: Evidence from a India-wide Randomized Policy Experiment,” Econometrica 72, no. 5 (2004): 1409-44; Timothy Besley, Rohini Pande and Vijayendra Rao, "Political Economy of Panchayats in South India," Economic and Political Weekly 42, no. 8 (2007): 661-6.

11 John Vidal, “UN Report: World's Biggest Cities Merging into 'Mega-regions," Guardian, March 22, 2010, http://www.guardian.co.uk/world/2010/mar/22/un-cities-mega-regions (accessed 2 August 2011).

12 Dewar and Epstein, "Planning for 'Megaregions," 109.

13 UN-HABITAT, State of the World's Cities, 99. 
states to form these institutions. ${ }^{14}$ This article steps away from normative abstractions towards empirical realities, and investigates the performance of regional institutions that are emerging on the ground to deal with the highway land conflicts.

\section{Institutional actors in land consolidation in India}

India is in the midst of a contested political debate on the question of how agricultural land should/can be acquired democratically to accommodate industrial and urban expansions. After more than a century, the 1898 Land Acquisition Act (LAA) - framed by the colonial government for land acquisitions and which continues to legislate compulsory land acquisition in the twenty-first century-is finally being debated for amendments in the Indian Parliament. The political class has been forced to revisit the LAA because of the violent land conflicts the country has been facing over the past decade: the Singur protests that forced the Tata Nano automobile factory out of West Bengal, the clashes over land acquisition for the Yamuna Expressway connecting Agra and Delhi, the human wall formed by protesting tribals against the land acquisition for the POSCO steel plant in Orissa. Though an amendment to an antiquated colonial law is long overdue, this alone will do little to solve India's land problems. A point that is missed in contemporary Indian debates on land acquisitions is that none of these conflictual land cases uses the LAA for their coercive compulsory acquisitions. Instead, all of them used parastatals for land acquisition: the Singur lands, for example, were acquired not through the use of the LAA, but by the industrial parastatal, the West Bengal Industrial Development Corporation. The LAA authorizes the state to compulsorily acquire land only for "public purposes." In India as elsewhere, the question as to whether the compulsory acquisition of land for private companies for economic development constitutes a public purpose is a hotly debated and unresolved one. ${ }^{15}$ The parastatals, on the other hand, have special legislation to acquire land explicitly for the purpose of industrial and urban development. ${ }^{16}$ It is these parastatals that are implicated in the recent land controversies and they are the focus of this article.

Urban lands in most Indian states are managed by parastatals. Agricultural lands are managed by district-level Revenue Departments. Revenue

14 Studies in other sectors like health also point to the difficulties of forming new institutions. For instance, Donnegan argues that new village-level institutions to monitor India's National Rural Health Mission program were not formed because these "new entit[ies] imposed by upstream policy makers [are] incompatible [with] preexisting social relationships downstream." Brendan Donnegan, "Spaces for negotiation and mass action within the National Rural Health Mission: 'Community monitoring plus' and people's organizations in tribal areas of Maharashtra, India,” Pacific Affairs 84, no. 1 (2011): 63 .

15 ALF, Of Master Plans and Illegalities in an Era of Transition (Bangalore: Alternative Law Forum, 2003).

16 ALF, Of Master Plans and Illegalities in an Era of Transition. 
Departments were initially set up in the late nineteenth century during colonial rule to extract taxes from agricultural lands, which were a significant source of colonial revenue. Agricultural lands continued to be vested with the Revenue Departments after Independence. The Revenue Department's District Collector (DC) mediates the negotiations between parastatals and agrarian landowners. The diagram below maps out the institutional actors and the steps involved in the consolidation and conversion of agricultural lands to 1) residential uses, and 2) industrial uses.

The institutional actors in residential land consolidation and conversion are the agrarian landowners, the Revenue Department, the residential parastatal if the state has one-the Bangalore region has residential parastatals like the Bangalore Development Authority, the Pune region does not-and the Village Panchayat. The actors are the same for industrial land consolidations, except that the industrial parastatal is involved instead of the residential parastatal.

A note on caste: The experiences of the agrarian landowners in land consolidation can be broadly stratified into caste-based experiences, with the opportunities, risks and uncertainties faced by the "dominant castes" 17 being very different from those faced by the low-caste Dalits and tribals. The dominant caste exercises control over other social groups as landowners, as main sources of credit and as elected representatives of the local democratic institutions. The dominant-caste landowners along the Bangalore-Mysore highway are the Vokkaligas, and along the Pune-Nashik highway the MarathaKunbis. The analytic of caste is a central part of this narrative, and I return to it in more detail in section 3 .

\section{Case Studies: The Bangalore-Mysore and Pune-Nashik Corridors}

\subsection{Bangalore-Mysore corridor}

The sample cluster of 28 villages along the Bangalore-Mysore highway is located in an area called Bidadi. The Bidadi area has seen dramatic changes in the past three decades, with large industrial and residential developments coming up amidst its otherwise agrarian landscape of millet and mango fields. This article focuses on three large developments in the Bidadi area: the Bidadi Industrial Area project, the Nandi Infrastructure Corridor Enterprise (NICE) township and the Bangalore Metropolitan Regional Development Authority (BMRDA) township.

\footnotetext{
17 Sociologist M.N. Srinivas coined the term "dominant caste" to describe social groups that "[preponderate] numerically over the other castes and ... [wield] preponderant economic and political power. A large and powerful caste group can more easily be dominant if its position in the local caste hierarchy is not too low." See M.N. Srinivas, "The Social System of a Mysore Village," in Village India, ed. Marriot Mckim (Chicago: University of Chicago Press, 1955).
} 

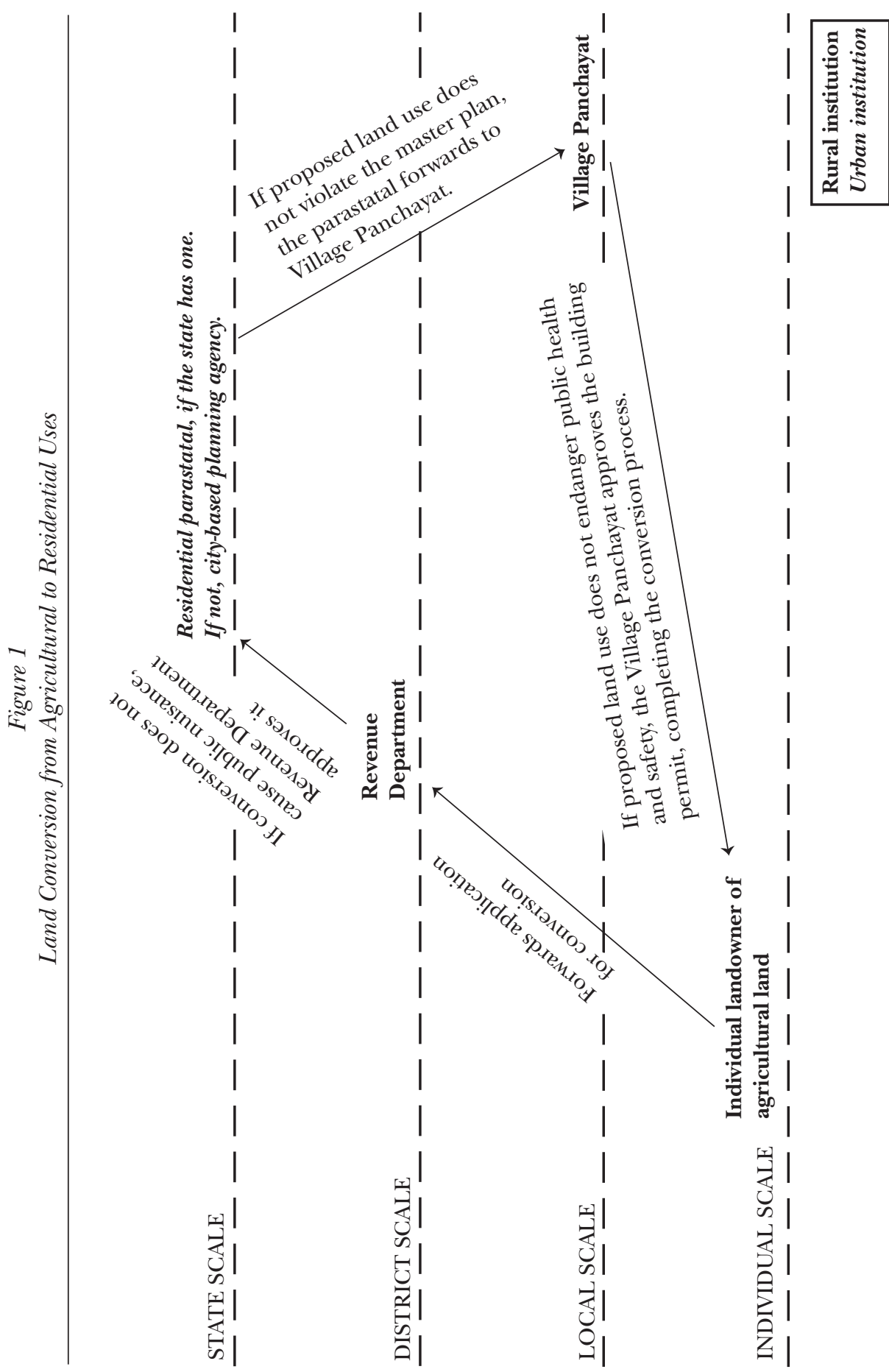
Pacific Affairs: Volume 86, No. 4-December 2013

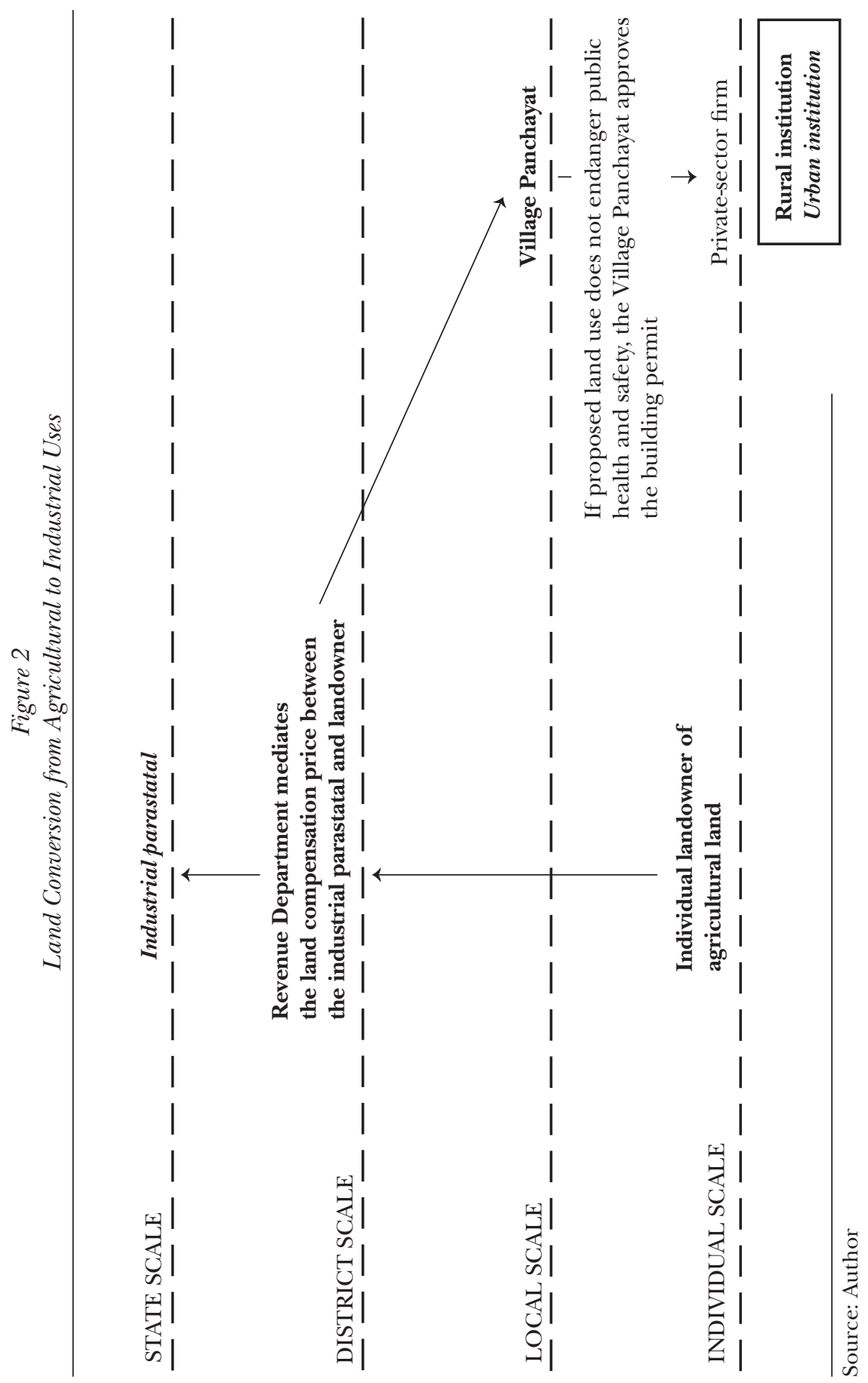




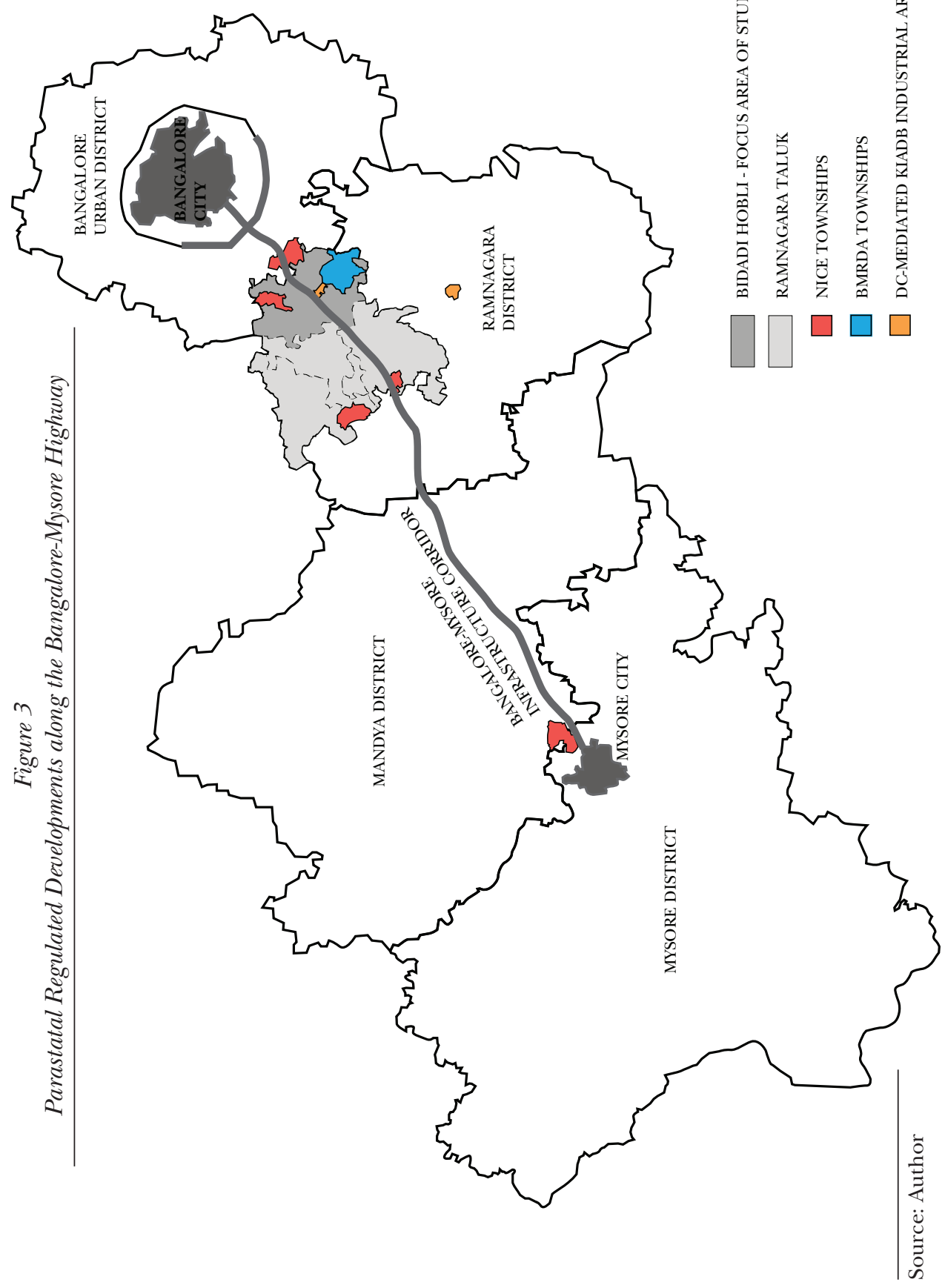




\subsubsection{Bidadi industrial area}

The largest industrial development along the Bangalore-Mysore corridor is the 750-acre Bidadi Industrial Area. Large multi-national companies, including Toyota and Coca Cola, have set up manufacturing plants here. C.M.L. is one of the most powerful politicians in Ramnagara district. His family is the largest sugarcane landowner in the area. Due to the agricultural labour shortage in the area, C.M.L. has now diversified his economic activities to education. He owns an engineering college in Bidadi and spends most of his time as administrator of his educational institution. C.M.L. was the Member of the Legislative Assembly (MLA) of Bidadi constituency in the mid-1990s, when the industrial parastatal, the Karnataka Industrial Areas Development Board (KIADB), approached him on behalf of the Japanese company Toyota. Since economic liberalization in 1991, India had shifted from a central-government-led model of balanced economic development to a more state-led model of territorial competitiveness. This shift meant that the state of Karnataka, in which the Bangalore-Mysore highway is located, had to compete with other Indian states to attract large-scale mobile capital. C.M.L. played a crucial mediating role between the industrial parastatal and his Bidadi constituents in consolidating land for the new industrial development.

In 1996, a Japanese team, Toyota, had come to this area. They wanted a factory. They had four to five options - one was at Noida, another Pune, third was Chennai, fourth was this one, fifth was Hyderabad. D. C. Thimmiah was the Chief Development Officer at KIADB. We were close. He met me and told me the team is coming: 'I will bring them here, whatever support you can give, give it.' I attended the meeting, farmers on one side, Toyota officers and state government officers on the other. I, as MLA, was in dhoti [a traditional garment worn by Indian males] and ordinary shirt, as though I was also one of the farmers. In the meeting, I assured them [Toyota] not to worry...That evening, when we were waiting with the Japanese Toyota representatives, without informing, unofficially, Mr. Chandrababu Naidu [then Chief Minister of Andhra Pradesh, the state in which Hyderabad is located] arrived here at the Taj Hotel to meet the Toyota team. Any convenience they wanted, he was willing to give: please come to Hyderabad. There was an invitation from the Chief Minister of Maharashtra to go to Pune. ${ }^{18}$

C.M.L. was at the crossfire of multiple, competing interests-the KIADB was applying pressure to find land for Toyota; at the same time, he could not afford to alienate his agrarian constituents through forcible land acquisition. Faced with these pressures, the best way to acquire large tracts of land for industry without agitating voters is to appropriate common lands for industrial development. The district-level Revenue Department owns all common lands 
within villages. To minimize political unrest, the MLA and District Collector identified the Bidadi area with its large tracts of common land as the site for the industrial area. The Revenue Department handed over the 144 acres of gomala land-common lands used as grazing grounds for cattle-to the KIADB. The District Collector then proceeded to negotiate with the 500-odd farmers of the plots adjacent to the grazing lands. Most of these farmers were peasant agriculturalists, with small landholdings of less than four acres. The District Collector, as the price-fixing authority, negotiated a land compensation rate with the farmers, and the negotiations were completed without any protests. The KIADB sold the acquired lands to twenty large industrial firms. C.M.L.'s family continues to be active in Bidadi politics: his son is now an elected representative of the Village Panchayat.

Landowners who gave up their lands for the industrial development have now transitioned to the industrial economy. Local residents aspire to permanent jobs in these industries, but many of them, even those with the requisite skills, are employed as unskilled daily-wage and contract labourers. The factories are reluctant to employ local labour for fear of unionization, but to avoid social unrest they permanently employ residents who are recommended by the Village Panchayat. The Bidadi Industrial Area is located within three Village Panchayats: Ittamadu, Manchanayakahalli and Bidadi. Sitamma is a Dalit-elected representative of Ittamadu Village Panchayat, and she outlined the procedure for a village resident to get a job in the factory:

\begin{abstract}
You [the person looking for a factory job] go to the Adhyaksh [head of the elected representatives] and give him a form. The factory will only accept you if the Panchayat recommends you. The factory does not take local labour because they will do galatta [stir trouble]. But adhyaksh phone madthare [the adhyaksh will call], then they will agree. You cannot go directly to the factory for a job, it is only through recommendation. You need good marks in the exams. It works on recommendation and education. These recommendations are for permanent jobs, and sometimes even for coolie [daily wage] jobs. ${ }^{19}$
\end{abstract}

Sitamma echoed the phrase "adhyaksh phone madthare" multiple times during our conversation, reiterating the critical role of the Village Panchayat head as the gatekeeper of these factory jobs. To fulfil Sitamma's urban aspirations for her son she is educating him in engineering and is confident that he will get a permanent factory job on graduating:

My son is in diploma college in Jnanabharati [a college in Bangalore] ...I cannot give him too much, the least I can do is give him an olle jeevana [good life]. After that [his diploma], he will get work in the factory.

Village residents with close connections to the elected representatives

19 Interview with author, 25 April 2011. 
have brighter prospects of landing the coveted permanent factory jobs. Others work as informal labourers, finding jobs through contractors who supply the factories with daily-wage labourers.

\subsubsection{Nandi Infrastructure Corridor Enterprise (NICE) township}

Though Bangalore-Mysore had a highway connection, in 1988, the government of Karnataka decided to construct a new six-lane corridor parallel to the existing one. The rationale for the corridor was to decongest Bangalore's development through spurring regional development along the new corridor, and to reduce travel speeds between Bangalore and Mysore. In 1994, the state government selected the NICE: a consortium of Pune-based Kalyani Group, Pennsylvania-based SAB Engineering and Boston-based Vanasse Hangen Brustlin. According to the build-own-operate-transfer contract, the industrial parastatal-the KIADB-would take on the responsibility of land acquisition for the 7000-acre toll-based corridor and an additional 21,000 acres for five new townships that would be developed along it. The infrastructure corridor would be transferred to the government after 30 years, but the townships along the corridor would be sold to the private consortium. The NICE corridor and its five townships have been mired in litigation since 1994, with nongovernmental organizations (NGOs) challenging the acquisition of agricultural lands for private township development. Karnataka has three competing political parties: the Congress, the Bharitiya Janata Party (BJP), and the Janata Dal-Secular (JD[S]). Though Deve Gowda, the JD(S) chief minister, signed the initial 1994 contract, he is now at the forefront of the protests against the NICE project. When the BJP came to power in 2008, the NICE consortium aligned itself with the BJP, and BJP politicians accused Gowda of instigating the farmers for his own political advantage.

\subsubsection{Bangalore Metropolitan Regional Development Authority (BMRDA) township}

In 2006, H.D. Kumaraswamy, then the chief minister of Karnataka, announced his intention of setting up the 9000-acre "knowledge city" project, called the Bidadi Integrated Township Project. The BMRDA advertised the project as "offer[ing] the same or more comforts/facilities as available in Bangalore city minus the congestion, traffic bottlenecks in a serene and environmentally rejuvenating atmosphere." The township is located within the boundaries of nine Village Panchayats. The project was to be implemented as a public-private partnership between the Bangalore Metropolitan Regional Development Authority (BMRDA) and the private developer. The BMRDA has the authority to plan the metropolitan region, but it does not have the authority to acquire lands. The BMRDA requisitioned the industrial parastatal for the state, the Karnataka Industrial Area Development Board (KIADB) to acquire land for the project. In October 2007, the BMRDA selected the 
Delhi-based DLF and the Dubai-based Limitless Holdings, in a 50:50 joint venture partnership, as the project developers.

As the BMRDA was going through the process of selecting the developer, the agrarian landowners whose lands were to be acquired for the Bidadi township project staged a protest in the district headquarters and they filed a writ petition in the Karnataka High Court against the BMRDA for proposing to acquire cultivable agricultural lands. This landowners' association, called Ranganatha Rytha Hitarakashan Samiti, consisted of around 200 aggrieved farmers, and it was led by four of the largest landowners in these villages. The majority of landholdings in these villages varied from one to five acres in size; the four leaders of the farmers' association owned around 60 to 80 acres of fertile, irrigated lands. One of these large landowners, Shivanna, was a Congress politician, and his opposition to the project stemmed from personal loss and political rivalry. When I met Shivanna in December 2010, it was clear that he had moved from township protestor to partner:

In January 2006, we did a dodda galatta [big protest]. The project did not have any benefits for farmers. Then the CM [Chief Minister, Kumaraswamy] called us. CM asked us, 'This is a good project, why are you protesting?' I said, 'Your project is good, but what is the benefit for farmers, for the losers?' He said the losers will get 60:40 deal - for every acre of land that we give up, $40 \%$ of the developed land will be returned to us. Now, we will not stop the project, but we need something that will benefit us. Through the 60:40 deal, farmers also get a valuable property... Here, the farmers are finding it difficult to practice agriculture. ${ }^{20}$

Due to agricultural labour shortages, larger landowners are agreeable to giving up their lands if the land consolidation deal is perceived to be fair. These landowners have learned from the Bidadi Industrial Area experience, and are willing to give up their land if they can also benefit from the land value increment of their rezoned lands:

In 1994, the government gave farmers a good rate, INR 600,000 [USD $\$ 12,000]$ per acre, but the farmers did not know how to use the money, and the lands are now more than ten times in value. We do not want to be in that situation. That is why we do not want the money. Through the 60:40 deal, we will get valuable property. ${ }^{21}$

Apart from this financial arrangement, Shivanna and the other local leaders were offered targeted incentives to lure them to cooperate with Kumaraswamy on the project. Though Shivanna was a Congress politician at the Village Panchayat level in 2006, he is now an elected representative at the district level on a JD(S) ticket.

With the burst in Dubai's property market following the 2008 global

\footnotetext{
$20 \quad$ Interview with author, 1 April 2011.

$21 \quad$ Interview with author, 1 April 2011.
} 
financial crisis, DLF's Dubai-based partner, Limitless Holdings, withdrew from the partnership and DLF pulled out of the Bidadi township project. In 2010, the BMRDA has resumed the project and is in the process of inviting RFPs (requests for proposals). The property market has changed since its earlier RFP, and one of the BMRDA decision-making bureaucrats said that a lesson learnt was against such large megaprojects. Township projects, like the 9000acre Bidadi one, should be parcelled into a number of smaller projects and tendered to different developers, both for quicker implementation and to make more developers eligible for the development process. But the project is inching along at a slow pace. The JD(S) lost the state elections in 2008 and the BJP came to power. A JD(S) local politician in Bidadi was positive that "the Bidadi township will start in full force once Kumar anna [referring to H.D. Kumaraswamy as 'big brother Kumar'] comes to power."

\subsection{Pune-Nashik corridor}

The land cooperatives along the Pune-Nashik corridor provide an instructive contrast to the Bangalore-Mysore parastatals. The first of these cooperatives is the Magarpatta township, formed in 2001. Though it is not located along the Pune-Nashik highway, I studied Magarpatta because it is the precedent for the other land cooperative cases. While the Magarpatta township is a voluntarily formed cooperative, in 2006, the first parastatal-mediated cooperative was formed in the Khed area, around 42 kilometres from Pune along the Pune-Nashik corridor. Inspired by the successes of the Magarpatta and Khed cooperatives, other land cooperative started proliferating in the Pune region. Soon after the formation of the Khed cooperative, the villagers of Avsari Khurd-a village adjacent to the Khed villages-pooled 3,500 acres of lands and approached the MIDC to lease their consolidated lands for industrial development. The villagers of the neighbouring villages of Chakan agreed to part with their lands for the proposed Pune International Airport if they could get a deal similar to the Khed farmers. The Revenue Department bureaucrats, instrumental in forming the Khed cooperative, have negotiated a similar package of leasing 5000 acres of land owned by farmers' cooperatives for industrial development in Sinnar, an area located 50 kilometres from Nashik along the Pune-Nashik corridor. In this paper, I focus on the voluntarily formed Magarpatta township and the parastatal-mediated Khed case.

\subsubsection{Magarpatta township}

The Magarpatta township is a 400-acre functional, middle-class enclave of apartments, bungalows, information-technology firms and schools. The landowning farmers who gave up their lands for the township own shares in the Magarpatta shareholding company in proportion to the land contributed. Before the 1990s, the Magarpatta area was the site of fertile sugarcane fields. The largest landowning family in Hadapsar was the joint family of the Magars, a politically influential network whose most prominent member, Annasaheb 
Magar, had been a Member of Parliament for the Congress Party in the 1970s. During his political tenure, Annasaheb Magar channeled many development projects to his home constituency of Hadapsar, including the setting up of a cooperative sugar factory to benefit the local sugarcane farmers.

The 1980s saw a wave of urbanization-related changes sweep over the Hadapsar area: the rising demand for the Hadapsar lands to accommodate Pune's explosive urbanization, and acute labour shortages with the Dalit labourers who lived and worked on the sugarcane fields now finding

Figure 4

Cooperative Regulated Developments along the Pune-Nashik Highway

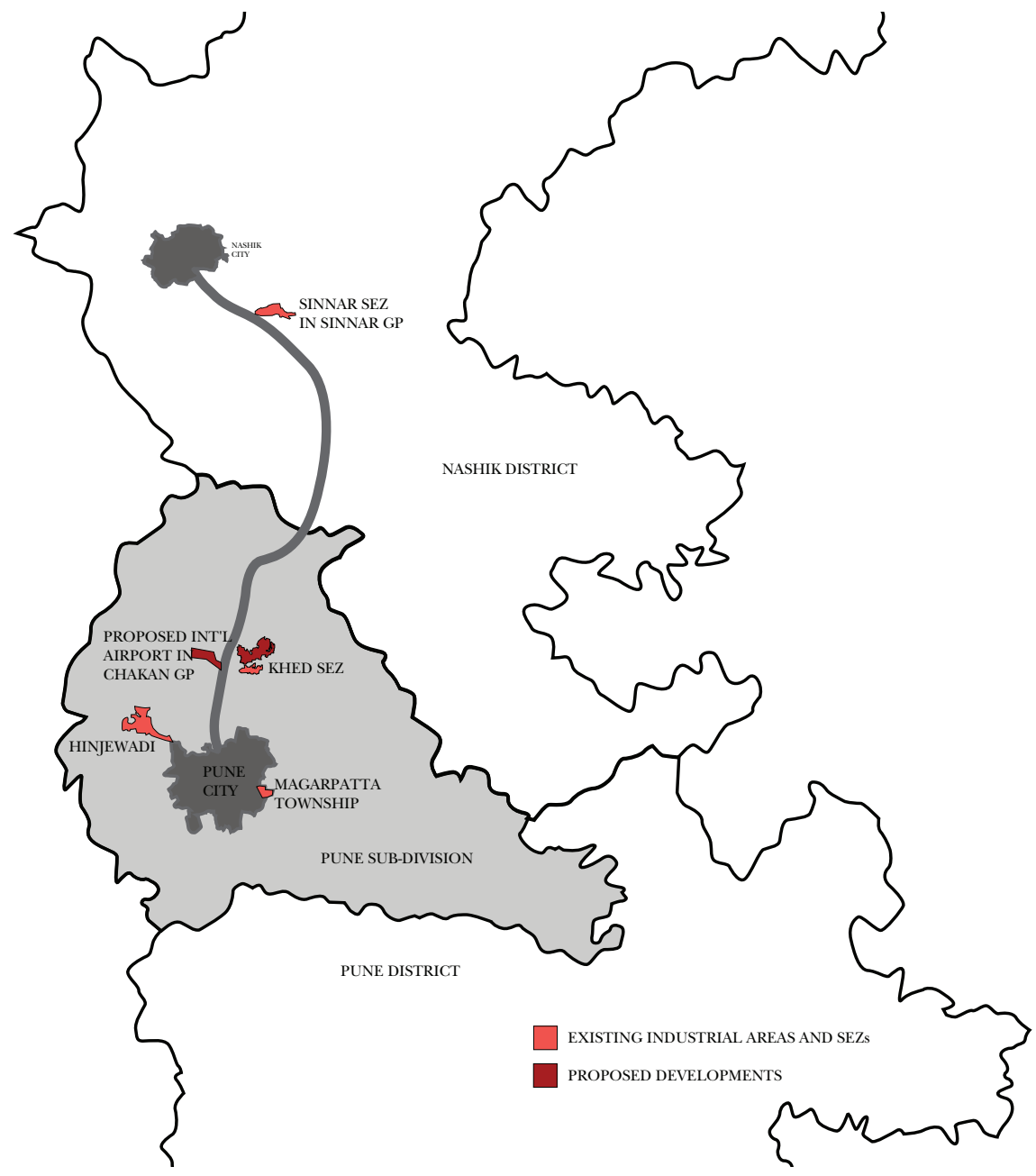

Source: Author 
alternative employment in Pune's informal economy. In the midst of these changes, the Magars saw an opportunity in land development. Annasaheb's nephew, Satish Magar, took the lead in convincing the other Magar landowners not to sell their lands individually to developers, and to instead pool their fragmented landholdings to form a township in collective ownership. The erstwhile sugarcane farmers are now developers-shareholders of the Magarpatta shareholding company.

The Magars' long political history in the area, and their strong political connections were a key factor in bringing the other farmers together in a collective land development experiment. The Magars' close political connections with top-level state government politicians of the ruling party, including the chief minister at the time, helped them navigate the land regulatory process. The state government granted the Magarpatta township two exemptions: an exemption from the Maharashtra Land Revenue Act condition, which stipulated that only agriculturalists can apply for a conversion of their agricultural lands to non-agricultural uses, and an exemption from the Urban Land Ceiling and Regulation Act, which enabled the state government to acquire urban lands beyond a certain threshold for redistribution for public purposes. Besides the state-level political connections, Satish Magar benefited from the trust relations that his family had cultivated with the area's sugarcane farmers over the past sixty years. A 70-year old farmer, who gave up four acres of his land for the Magarpatta township, spoke of the landowners' trust in the Magar family:

I have been farming here since $1965 .$. In 1993, our Magar family had a meeting, and all of us were convinced of the [Magarpatta] project. We gave a signature, we did not ask anything, we just gave our signature. We trusted Satish Magar. Annasaheb Magar became an MP [Member of Parliament] from here. He started a sugar factory here for the farmers - 20 kilometers from here. All our sugarcane went to this factory. Like Annasaheb Magar helped us, Satish Magar is also helping the farmers with the township. ${ }^{22}$

Stories of Magarpatta's success have spread to other regions around Pune. When the bureaucrats of a neighbouring group of villages in Khed faced resistance against the land consolidation of agricultural land for a new industrial development, they adapted the Magarpatta solution to reconcile their land conflict.

\subsubsection{Khed SEZ}

In 2006, Bharat Forge, an Indian company that manufactures automobile components, identified 16,800 acres of land in 17 villages in Khed taluk. The Khed agrarian landowners opposed the proposed development, and eminent

22 Interview with author, 23 May 2011. 
activists and politicians of oppositional political parties congregated in Khed to join the landowners' agitation. The industrial parastatal-the MIDCapproached the District Collector of Pune district to mediate the land consolidation process. The District Collector had worked in the MIDC for five years before his transfer to the Revenue Department, and he had a close working relationship with MIDC bureaucrats. He delegated the power to acquire lands for Bharat Forge to his Revenue Department bureaucrat at the sub-district level, Shyam Patil. As a street-level bureaucrat of the Revenue Department, Patil was familiar with the local leaders of these villages. Most of the villages along the Pune-Nashik corridor and more broadly, in western Maharashtra, where this highway is located, are characterized by peasant agriculture. However, the villages have a few influential families that own larger tracts of land and are politically powerful. Negotiations between the local leaders and Patil resulted in an agreement whereby 15 percent of the acquired lands will be developed and returned to the farmers to form a land cooperative. Like the Hadapsar area in the Magarpatta case, the Khed villages are also facing acute agricultural labour shortage because many of the agricultural labourers-mainly tribals - are finding alternative informal work in the factories coming up along the Pune-Nashik highway. Though the Kelkars and the other local leaders are eager to transition from an agricultural economy that is fraught with challenges-like labour shortage-to an industrial economy, they initially resisted the Khed development because they felt cheated by the cash compensation offered for their land. Patil was keen enough to recognize their urban aspirations and negotiated a more attractive deal of the land cooperatives with them.

Phase 1 of Khed city is located within four Village Panchayats: Kanersar, Nimgaon, Dhawadi and Shirur. Mohanseth Kelkar, the Police Patil of Kanersar (the Village Panchayat-elected representative in charge of law enforcement) and Ramarao Kelkar, the Village Panchayat Sarpanch leader at the time of the negotiations, explained the Khed land consolidation process:

Earlier, even we had protested against the industry. Sarpanches of the 17 villages got together, formed an organization and in that protest, we went to the District collector's office. We went there asking them to close it [the industry]. With Patil saab [Shyam Patil], we discussed what will happen if the industry comes here. Because of this discussion, four villages immediately agreed to the industry. Kanersar was the first village to agree.... Patil saab told us, 'you prepare your people, we will arrange whatever you need.' We went around all the farmlands in the village, what to keep and what to remove, we underlined that. We had a gram sabha [village assembly] and convinced the people. ${ }^{23}$

The local leaders of the four consenting villages were promised construction and other jobs as additional incentives to convince their villagers

23 Interview with author, 15 January 2011. 
to join the project. Construction work has started in the Khed area, and one of the projects underway is the construction of homes for those villagers whose homes had been located on lands given up for industry. Mohanseth Kelkar, Ramarao Kelkar and two other friends have got together to form a construction company to take over the construction contract for these homes. The Bharat Forge employee supervising the construction said the farmers' newly formed construction company is slow in its work, and quality is not up-to-the-mark, but these concessions have to be made as "confidencebuilding measures."

Khed city is now owned by the Khed Economic Infrastructure Private Limited (KEIPL), a joint venture company between the private-sector firm, Bharat Forge, the industrial parastatal, MIDC, and the farmers' cooperative, Khed Developers Limited. The residents of the four villages will elect one representative each at the Gram Sabhas, the village deliberative assemblies, and these representatives will participate in KEIPL decision making. The chief executive officer of the KEIPL is a bureaucrat from the Maharashtra Industries Secretariat, with experience in industrial development. As of May 2012, houses for rehabilitating the displaced residents had been completed, and construction work has started on the boundary walls for the development.

\section{India's Hybrid Institutions: Parastatals and Cooperatives}

\subsection{Emergence of parastatals, then and now}

Parastatals, as politically insulated institutions, have been accused of bypassing local elected representatives and advancing pro-growth developer and business interests. ${ }^{24}$ Bangalore's parastatals - the Bangalore Development Authority (BDA) and the Karnataka Industrial Areas Development Board (KIADB) - have been mired in litigation during the past two decades over their coercive land acquisition practices, and they have been branded as "land brokers" 25 and the "new decision makers" to whom decision making has been "outsourced." ${ }^{26}$ These criticisms, though justified in light of the coercive land acquisition practices of parastatals, elide the long institutional history of parastatals in India and the changes in the functioning of parastatals since their emergence in the late nineteenth century to now.

India's parastatals trace their emergence to the City Improvement Trust Boards (CITBs) set up in the late nineteenth century by the colonial

24 Burns, The Formation of American Local Governments: Private Values in Public Institutions; Solomon Benjamin, "Governance, economic settings and poverty in Bangalore," Environment and Urbanization 12, no. 1 (2000): 35-56.

25 James Heitzman, Network City: Planning the Information Society in Bangalore (New Delhi: Oxford University Press, 2004): 55.

26 Kathyayini Chamaraj, "Parastatals and Task Forces: The New Decision-Makers," India Together, 22 February 2009, http://www.indiatogether.org/2009/ feb/gov-parastate.htm (accessed 2 August 2011). 
government. The CITBs acquired agricultural lands outside the city boundaries and built India's first planned suburbs. ${ }^{27}$ The CITB activities were partly a move to relocate the native poor from slums to these "model hygienic suburbs" in response to the plague epidemics sweeping through colonial cities, ${ }^{28}$ and partly a legitimization of colonial rule through demonstrating the civilizing effects of these rationally planned suburbs over the unsanitary and chaotic native settlements. ${ }^{29}$ The colonial government framed the Land Acquisition Act-the subject of much recent controversy and debate in India-in 1898 to enable the conversion of agricultural lands in the peripheries into CITB planned suburbs. After Independence in 1947, the demand for urban land continued with the expansion of Indian cities under Nehru's policies of state-led industrialization. It is at this point that the institutional histories of the Bangalore and Pune regions start to diverge. The planning of new suburbs, and the extension of infrastructural services (mainly water supply and sanitation) to them, is a capital-intensive activity. Cities like Mumbai in Maharashtra, with a flourishing industry and large tax bases, had the financial capabilities to manage these capital-intensive expansions of serviced land. ${ }^{30}$ Cash-strapped cities like Bangalore, on the other hand, turned to international financial institutions like the World Bank, which recommended the setting up of parastatals for more efficient land and service delivery. ${ }^{31}$ In response to fiscal pressures, the Bangalore Water Supply and Sewerage Board (BWSSB) was established in 1964, followed by the Bangalore Development Authority (BDA) in 1976 as a successor to the CITB. Pune and Mumbai do not have land and water parastatals, and their land, water supply and sanitation responsibilities continue to be managed by the local government. The local governments in Mumbai and Pune in Maharashtra have experimented with innovative models of land consolidation, like the Town Planning Scheme-commonly called land pooling or land readjustment, where the local government brings together disparate agrarian landowners within a certain boundary and reassembles their fragmented, agricultural landholdings into serviced plots of regular dimensions ; and Transfer of Development Rights, where landowners give up their lands for public purposes in exchange for a transfer of their "Floor Space Index" (or Floor Area Ratio [FAR] as it is called in the US) to another

27 Janaki Nair, The Promise of the Metropolis: Bangalore's Twentieth Century (New Delhi: Oxford University Press, 2005).

28 Nair, The Promise of the Metropolis, 51; Prashant Kidambi, The Making of an Indian Metropolis: Colonial Governance and Public Culture in Bombay, 1890-1920 (Aldershot, 2007); Stephen Legg, Spaces of Colonialism: Delhi's Urban Governmentalities (Malden, MA: Blackwell Publishing, 2007).

29 Nair, The Promise of the Metropolis, 51; Kidambi, The Making of an Indian Metropolis; Legg, Spaces of Colonialism.

30 NIUA, Urban Governance Decentralization in India: A Review (New Delhi: National Institute of Urban Affairs, 2004).

31 K.C. Sivaramakrishnan and Leslie Green, Metropolitan Management: The Asian Experience for the Economic Development Institute of the World Bank (New York: Oxford University Press, 1986). 
location. Though the Karnataka Town and Country Planning Act has enabling legislation for land pooling schemes like the Town Planning Scheme, the reliance on urban parastatals like the BDA and the KIADB to acquire land through eminent domain precluded the need for local governments to get involved in land consolidation responsibilities. ${ }^{32}$ Not surprisingly, local governments in the Bangalore region lack the institutional capacity to implement land consolidation projects.

Conflicts and litigations over the compensation for compulsorily acquired land have been ongoing since the start of CITB activities in the late nineteenth century. ${ }^{33}$ But, the land conflicts today have escalated to an unprecedented level of political urgency, and the 1898 Land Acquisition Act is finally being debated and amended in the Parliament. The reason for this belated debate of a century-old act is that, for the first time, the dominant-caste agrarian landowners are challenging the coercive acquisition of their agricultural lands for urban/industrial expansion. The rising environmental awareness on the need to protect grazing lands, lakes and other "urban commons" is making it more difficult for bureaucrats and politicians to acquire these lands for industrial and urban expansions. ${ }^{34}$ However, parastatals and politicians cannot coercively acquire lands from agrarian landowners as the dominant-caste agrarian landowners have been an important political constituency since Independence. ${ }^{35}$ Dominant-caste agrarian landowners, like Shivanna along the Bangalore-Mysore highway, and the Kelkars along the Pune-Nashik highway, have aspirations to be a part of the "India Shining" growth story and to transition to an industrial economy and an urban lifestyle. Coupled with these aspirations are the challenges facing an agrarian lifestyle: the dismal prospects of an agricultural future given the vagaries in weather conditions and the shortage of agricultural labour due to labour migration to the informal industrial economy. Though eager to transition to an urban/ industrial economy, dominant-caste agrarian landowners will do so only under conditions that are perceived to be fair to them. They are learning from the past experiences of those who gave up their agricultural land for

32 A. Ravindra, B.K. Chandrashekar, V. Govindraj and P.S.S. Thomas, The Committee on Urban Management of Bangalore City, Report Submitted to Government of Karnataka (Bangalore: Government of Karnataka, 1997), 129.

33 Kidambi, The Making of an Indian Metropolis.

34 The Indian journal, the Economic and Political Weekly, launched a selection of papers on the "urban commons"-common resources—in its 2011 Review of Urban Affairs, and some of the papers looked specifically at the depletion of water bodies and common lands because of unregulated urbanization: Economic and Political Weekly 66, no. 50, December 10, 2011. On the government side, the Karnataka legislature set up the Karnataka Public Lands Corporation for investigating the encroachments on government lands, and for recommendations to existing laws to prevent these encroachments: Karnataka Legislature Joint House Committee, Bangalore City/Urban District Encroachment of Government Lands, Interim Report Parts 1 and 2 (February and July, 2011).

35 Ashutosh Varshney, Democracy, Development and the Countryside: Urban-Rural Struggles in India (Cambridge University Press, 1998); Achin Vanaik, The Painful Transition: Bourgeois Democracy in India (London: Verso, 1990). 
industrial/urban projects in the 1990s and early 2000s, and the raw deal they got in accepting then-prevalent market rates as compensation for land that is now almost ten to twenty times in value. Local politicians and bureaucrats are innovating with new arrangements-like returning 40 percent of the developed land to landowners in the BMRDA case and the formation of land cooperatives in the Khed case-that are more inclusive of this agrarian constituency in the benefits of urbanization. Of the five highway cases studied, it is only the NICE project along the Bangalore-Mysore highway that continues to acquire land in a coercive, top-down manner. This could be because the NICE project is supported by the political party, the BJP, which has not developed a local, cadre-based presence in Southern Karnataka.

The Bangalore-Mysore and Pune-Nashik cases alert us to the emergence of three types of agrarian landowning leaders, whose demands for more inclusive development are leading to reconciliatory arrangements like land cooperatives:

- Leaders like Satish Magar blur the distinctions between industrial/ urban capitalists and agrarian landed elites. Such leaders have the political, social and cultural capital to "[blunt] the customary contradiction between industrialization on the one hand and the existence of the peasantry on the other," ${ }^{36}$ but they are few and far between.

- More common are leaders like the Shivanna in the BMRDA case and the Kelkars in the Khed case. These agrarian landed elites have the urban aspirations to transition to an industrial/urban economy, but they lack the political and economic resources of the Magars to make this transition themselves. However, they are powerful enough as local leaders to effectively block any urban developments that are not beneficial to them, and the industrial/urban capitalists and the bureaucracy/politicians cannot ignore them.

- With decentralization reforms like quotas for Dalits and women, a new political class of decision makers is emerging at the Village Panchayat level. Some researchers point to the positive outcomes of these decentralization reforms, like the changes in the allocation of public resources to benefit previously excluded groups like women and Dalits. ${ }^{37}$ Others are more sceptical of these reforms, arguing that decentralization has not led to a diffusion of power to citizens, but has consolidated power at the level of Village Panchayats. ${ }^{38}$ Though the verdict is still out, it is clear that the decentralization reforms are changing the composition of local

36 Varshney, Democracy, Development and the Countryside, 26.

37 Chattopadhyay and Duflo, "Women as Policy Makers: Evidence from a India-wide Randomized Policy Experiment"; Besley, Pande and Rao, "Political Economy of Panchayats in South India."

38 Peter Ronald de Souza, "Legislation and Administrative Reform," Background Paper no. 1 in the World Bank's Overview of Rural Decentralization in India, volume 3, 2000; Ruth J. Alsop, Anirudh Krishna and Disa Sjoblom, "Are Gram Panchayats Inclusive? Report of a Study Conducted in Rajasthan and Madhya Pradesh," Background Paper no. 3 in World Bank's Overview of Rural Decentralization in India, volume 3 (2000). 
democratic institutions and unsettling entrenched constituencies like the dominant-caste agrarian landowners. The influence of this new class of local decision makers on highway urbanization remains to be seen.

The point to underscore is that, in emergent settlement transitions like the inter-urban highways, urban parastatals cannot continue with their old coercive practices of land acquisition. The local bureaucrats along the PuneNashik highway have played a central role in mediating land consolidation processes between the parastatals and agrarian landowners. The better performance of the Pune bureaucrats is partly because they are experienced in dealing with TPS and other land assembly methods, unlike the Bangalore bureaucrats, who delegated this responsibility to the urban parastatals, and partly because the Pune region has a long history of sugar cooperatives that is now being reworked into land cooperatives to benefit dominant-caste agrarian landowners. The next section focuses on the emergence and evolution of cooperatives in the Pune region vis-à-vis the Bangalore region.

\subsection{Emergence of cooperatives, then and now}

The new institutional experiments around the Pune region have been praised by the Indian media and policy makers alike as "inclusive capitalism" 39 and "an equitable model for land acquisition." 40 The first of these cooperative experiments is the voluntarily formed Magarpatta township. Magarpatta traces its institutional origins to the Pune region's thriving sugar cooperatives, first set up in the 1940s. This section asks why certain regions of the country, like the Western Maharashtra region, where the Pune-Nashik highway is located, have a rich cooperative history, and others, like the Southern Karnataka region, site of the Bangalore-Mysore highway, do not. Why did cooperative formation in a particular commodity (sugar) burgeon from the 1940 s to the 1980s, and why are cooperatives in a different commodity (land) emerging in the same region? Within the Pune region, why are cooperatives emerging in different forms: as voluntarily-formed cooperatives in the Magarpatta case and as parastatal-mediated cooperatives in the Khed case? The answers to these questions can shed light on the transferability of the idea of cooperatives to regions like Bangalore that lack a cooperative history, and on the conditions under which different forms of cooperatives can be formed in different regions.

The emergence of sugar cooperatives in some regions of the country, and not others, is linked to dominant-caste agrarian politics and the implementation of land reforms. Soon after Independence in the late 1940s, the democratically elected Congress Party implemented its first phase of

39 India Knowledge @ Wharton, The Poor as Stakeholders: Can 'Inclusive Capitalism' Thrive in India? (November 2008), http://knowledge.wharton.upenn.edu/india/article.cfm?articleid=4336 (accessed 6 June 2011).

40 Rakesh Ganguly, "The Magarpatta Model of Land Acquisition," Infochange News and Views (April 2008). 
land reforms for the abolition of intermediaries-like the zamindars, inams, jagirs - the non-cultivating propertied class inserted between the cultivators and the colonial state as part of indirect rule. With the overthrow of these intermediaries, a new class of beneficiaries-the cultivators who had worked on the lands of the intermediaries-emerged, who became the backbone of Indian democracy in the first few decades after Independence. ${ }^{41}$ Some of India's most successful commodity cooperatives, such as the sugar cooperatives in Western Maharashtra and the milk cooperatives in Gujarat, took root in regions where the beneficiaries from the first phase of land reforms-like the Maratha-Kunbis in the former case and the Patidars in the latter-demanded state support to successfully participate in the market economy. ${ }^{42}$ Western Maharashtra's sugar cooperatives got a fillip during the second phase of land reforms in the 1960s and 1970s, the focus of which was the Land Ceiling Act, dealing with the redistribution of surplus lands to the landless. The dominant-caste agrarian landowners who had pushed for the abolition of agrarian intermediaries in the first phase of land reforms resisted the second phase because it threatened their power base. The Maratha-Kunbis in Western Maharashtra circumvented the land ceiling reforms by reallocating their lands to different family members, ${ }^{43}$ and forming sugar cooperatives with their extended family as members. In contrast, the regional elites in Southern Karnataka—the Vokkaligas—exercised control over the marginal landowners not through tenancy, but through indebtedness. ${ }^{44}$ The Vokkaligas are the main source of credit to marginal landowners, and the credit-based form of control precluded the need for forming cooperatives or other institutions to circumvent land redistribution. ${ }^{45}$

The Magars are Maratha-Kunbis. For the past four decades, the agrarian landowners in the Magarpatta area cultivated sugarcane and were members of the sugar cooperative factory set up in 1969 by Satish Magar's uncle, Annasaheb Magar. It is this long sugar cooperative history that enabled the Magars to transition from the sugar cooperatives to land cooperatives. But, the transition from one commodity cooperative to another is not as easy as it sounds. For instance, it is easier to convince sugarcane cultivators to join a cooperative because sugarcane is a highly perishable commodity: sugar cannot be extracted from it unless it is processed within 24 hours of

41 David Hardiman, Peasant Nationalists of Gujarat: Kheda District 1917-1934 (New Delhi: Oxford University Press, 1981); D.N. Dhanagare, Peasant Movements in India 1920-1950 (New Delhi: Oxford University Press, 1983).

42 Vikash N. Pandey, "Agrarian Transformation and Co-operatives: Continuity and Change," Economic and Political Weekly 29, No. 15 (1994): 863-869.

43 Pani, Reforms to Pre-empt Change, Bipan Chandra, Aditya Mukherjee and Mridula Mukherjee, India Since Independence (New Delhi: Penguin Books, 2008).

44 Pani, Reforms to Pre-empt Change.

45 Pani, Reforms to Pre-empt Change. 
harvesting. ${ }^{46}$ This is a strong incentive for sugarcane cultivators to send their crops to the sugar cooperative. Landowners, on the other hand, have the option of holding on to their land in anticipation of higher market prices, and it takes more effort to convince them to join a land cooperative. Sugarcane cultivators also face lower risks in joining a sugar cooperative because, at a time, they give up a semi-annual, or at the worst, an annual harvest of sugarcane production to the cooperative. Members of a land cooperative, on the other hand, face higher sunk costs and higher opportunity costs in giving up all of their land towards their cooperatives. It takes more convincing and stronger degrees of trust for landowners to come together in a collective land enterprise than it does to join a sugar cooperative. The long history of trust between Satish Magar's family and the agrarian landowners of the Magarpatta area was crucial to the formation of the land cooperative.

The Magars were successful in voluntarily forming a land cooperative because of their past cooperative history, albeit in a different commodity (sugar), more concentrated patterns of land ownership, and an agrarian landowner class that doubles up as the industrial/urban capitalists. On the other hand, the less-educated Khed agrarian landowners, with their fragmented land holdings, lacked the technical expertise and political will to replicate the Magarpatta success. The Khed land consolidation process would not have been possible without the mediation of the Revenue Department bureaucrats: the District Collector and his sub-divisional officer, Shyam Patil. Both of these bureaucrats had worked in the industrial parastatal, the MIDC, before being transferred to the Revenue Department. As MIDC bureaucrats, they had been involved in 2003 in the land acquisition for phases 1 and 2 of an information-technology (IT) park, called Hinjewadi, on the outskirts of Pune. The agrarian landowners had received cash compensation from the MIDC for their acquired lands. By 2007, when the MIDC and the Revenue Department approached the villages around Hinjewadi for acquiring more land for phases 3 and 4, they were met with stiff opposition. Agrarian landowners had witnessed the rollercoaster journey of earlier landowners from "farmers to millionaires to unemployed" 47 and refused to give up their lands for future industrial expansion. In areas that lacked past experiences of collective action, the Revenue Department/MIDC bureaucrats realized that including agrarian landowners as equity members of a land cooperative can cultivate relations of trust among these landowners and the bureaucracy, thus increasing chances of collaboration for future industrial/

46 Trilochan Sastry, How Commodity Cooperatives differ from Milk or Sugar Cooperatives, http:/ / www. techsangam.com/2011/08/01/how-commodity-cooperatives-differ-from-milk-sugar-cooperatives / (accessed 27 July 2012).

47 Ketaki Ghoge, “A Pune Journey: Farmers to Millionaires to Unemployed," Hindustan Times (March 2009). 
urban expansions. As pointed out earlier, local bureaucrats in the Pune region had the institutional capacity to implement land assembly projects, through their past experiences of working on the Town Planning Scheme and the TDR. Interactions with Satish Magar following the resounding success of Magarpatta led to the idea of parastatal-mediated cooperatives for Khed.

In contrast to the Pune region, the reliance of the Bangalore region on the urban parastatals for land acquisition, the lack of institutional capacity to envision and implement land consolidation through non-coercive methods, and the lack of a cooperative history are some of the reasons Bangalore's local politicians and bureaucrats have not come up with institutional solutions like their Pune counterparts. It is too early to say if astute politicians and bureaucrats in the Bangalore-Mysore region will attempt to replicate the Khed case of parastatal-mediated cooperatives (if the Khed case turns out to be as successful as the Magarpatta one), or if they will re-work some other existing institution to reconcile their land conflicts.

\subsection{Parastatal-mediated cooperatives as emergent regional institutions}

Pune's land cooperative experiments-Magarpatta township and Khed city-occupy an ambiguous institutional space between the state and the market. They overcome local agrarian landowners' resistances to industrial/ urban land consolidations through the land cooperative dimension, but their registration as private companies allow them to structure capital like market institutions. The Magars were clear in their intention to set up "a private limited company knowing well that the initiative involved so many people and therefore a strong leadership was required, which we found in Satish Magar. ${ }^{48}$ Regional institutions like the Khed Economic Infrastructure Private Limited (KEIPL) are a complex assemblage of a land cooperative, an industrial parastatal, and private-sector firm, with the intention of leveraging the comparative advantages of these different institutions. The land cooperative is essential in gaining the trust and consent of agrarian landowners. The endemic problem of poor land records, unclear land titles and property disputes in India makes direct land transactions between private-sector firms and agrarian landowners risky for the private sector. However, when land is acquired by the state and transferred to the privatesector firm, the transferred land is declared free of encumbrances. The parastatal plays a crucial role in negotiating with a large number of fragmented landowners, and conveying unencumbered land to the private sector. The private-sector firm has the technical and financial expertise to deal with such large-scale industrial/property developments. Complex hybrid institutions like the KEIPL leave many questions unanswered. In this complex 
interlinking of a cooperative with a private for-profit company, whose interests-agrarian landowners or industrialists-is the KEIPL accountable to? How are clashes in interests reconciled within the organization? How are risks allocated among these different institutional actors? Are our current regulatory institutions-the Registrar of Cooperatives for cooperatives, the Committee for Public Sector Undertakings for public companies and the Registrar of Companies for private-sector companies-capable of regulating these complex hybrids that lie somewhere between public and private institutions? Understanding how these empirical innovations like the KEIPL work can lead, ex ante, to new regulatory frameworks that provide oversight to these emergent organizations.

\section{Conclusion: Negotiated Decentralization}

The urgent demand for agricultural lands along highways to accommodate rapid urban and industrial expansions, the inability of urban and rural local governments in managing these trans-local land transformations and the agitations of a politically important constituency-the dominant-caste agrarian landowners-for inclusion in the benefits of the new highway developments, are impelling local politicians and bureaucrats to experiment with new regional institutions to manage these highway urbanizations. The parastatal-mediated cooperatives are one such example in India. Other countries that are facing similar land and urbanization challenges are also coming up with context-specific responses to these large-scale territorial transformations. For instance, joint venture companies ${ }^{49}$ and shareholding cooperative companies $s^{50}$ are emerging as a common response to land conflicts in China. Similar to the dominant-caste agrarian landowners in India, the organized village collectives in China have been at the forefront of retaliations against the urban governments' requisitioning of agrarian lands from collectives for sale to industrialists and property developers. Negotiations between village collectives and urban governments have led to the reorganization of village collectives into shareholding cooperative companies, with the urban government returning a certain percentage of appropriated, rezoned land to these shareholding companies..$^{51}$

These findings challenge our conventional assumptions of decentralization, as a unidirectional devolvement of decision making from a higher to lower level of government. Instead, I use the term "negotiated decentralization" to reflect the actual back and forth tug-of-war between local and regional

49 Chengri Ding, "The Effects of Land Acquisition on China's Economic Future," Land Lines 16, No. 1 (2004): 11-13.

50 You-tien Hsing, The Great Urban Transformation: Politics of Land and Property in China (Oxford University Press, 2010).

51 You-tien Hsing, "Village Corporatism, Real Estate Projects, and Local Autonomy," in The Great Urban Transformation, 122-155. 
actors in managing trans-local geographies like highway urbanizations. The negotiated solutions-like parastatal-mediated cooperatives in India and shareholding cooperative companies in China-are contingent responses to local centres of power, the institutional forms through which these local interests have historically articulated themselves, and the reworking of these existing institutions to new forms to reconcile the new challenges of urbanization. These negotiated solutions defy our conventional categories of local-regional and urban-rural, with the emergence of leaders like Satish Magar who straddle these categories. Instead of simplified normative abstractions, these empirical complexities can provide the grist for crafting new grounded theories on emergent phenomena like highway urbanizations and regional institutions.

Harvard University, Cambridge, USA, May 2013

\section{The leading source of knowledge on Canada's Asia Pacific relations}

\section{The Asia Pacific Foundation of Canada offers:}

* Post-Graduate Research, Media and Senior Fellowships

* Grants for the Canada Asia-Agenda

* A free subscription service to news, reports, analyses and editorials

\section{Please visit asiapacific.ca for more information}




\section{CONTRIBUTORS TO THIS ISSUE}

Yooll BAe is an assistant professor of Political Science at Singapore Management University. His research covers various governance issues in Korea, Japan and Northeast Asia with particular emphasis on urban and environmental issues. He has recently published articles in academic journals such as Democratization and the Pacific Review. Email: yooilbae@smu.edu.sg

SAI Balakrishnan completed her PhD in Urban Planning at Harvard University and is currently a postdoctoral research scholar at the Columbia Law School's Center on Global Legal Transformation. Email: sbalakrishnan@law.columbia.edu

Tim Bunnell is an associate professor in the Department of Geography and in the Asia Research Institute at the National University of Singapore. He is currently conducting research on urban policy and transformation in Solo, Indonesia as part of a collaborative research project on Aspirations, Urban Governance and the Remaking of Asian Cities. Email: geotgb@nus.edu.sg

Mike Douglass is a professor and leader of the Asian Urbanisms Cluster in the Asia Research Institute and professor of Sociology at the National University of Singapore. Email: arimike@nus.edu.sg

Lisa Hoffman has a PhD in cultural anthropology and is an associate professor of Urban Studies at the University of Washington, Tacoma. Her current research examines volunteerism and philanthropy as new modes of solving social problems in urban China, and in 2010 she published a book titled Patriotic Professionalism in Urban China: Fostering Talent (Temple University Press). Email: hoffmanl@u. washington.edu

Diya Menra is an assistant professor of Sociology at South Asian University.

Michelle Ann Miller is a research fellow at the Asia Research Institute, National University of Singapore. She has authored, edited or co-edited a number of books including: Autonomy and Armed Separatism in South and Southeast Asia (ISEAS, 2012); Ethnic and Racial Minorities in Asia: Inclusion or Exclusion? (Routledge, 2012); and (with Tim Bunnell) Asian Cities in an Era of Decentralisation (Routledge, 2013). Email: arimam@nus.edu.sg

Nicholas A. Phelps is a professor of Urban and Regional Development at the Bartlett School of Planning, University College London. His research interests cover economic geography and the politics and planning of city-regions. He is author of An Anatomy of Sprawl (Routledge, 2012) and co-editor of International Perspectives on Suburbanization (Palgrave-MacMillan, 2011). Email: n.phelps@ucl.ac.uk

JOHN TAYLOR is an urban planner and activist. Over the last ten years he has worked in Latin America, Africa and Asia on a range of governance and urban issues. He lives and works in Indonesia where he is the director and founder of the local NGO "Yayasan Kota Kita" (Our City Foundation), whose mission is to improve participatory planning and budgeting processes by making information available to citizens. He has also served as a consultant to UN HABITAT, Mercy Corps and The Asia Foundation. He received his Masters in Urban Planning from Harvard University. Email: indojota@gmail.com 
Reproduced with permission of the copyright owner. Further reproduction prohibited without permission. 